\title{
IMPLEMENTASI MODEL PEMBELAJARAN BERDASARKAN MASALAH (PROBLEM BASED INSTRUCTION) UNTUK MENINGKATKAN AKTIVITAS DAN HASIL BELAJAR PKN SISWA KELAS VIIIA SEMESTER 2 SMP NEGERI 1 PEKUTATAN TAHUN PELAJARAN 2013/2014
}

\author{
Made Mitha Susanthi Ariasih, Dr. I Gusti Ketut Arya Sunu, M.Pd, \\ Drs. I Ketut Sudiatmaka, M.Si \\ Jurusan Pendidikan Pancasila dan Kewarganegaraan, Fakultas IImu Sosial, \\ Universitas Pendidikan Ganesha Singaraja, Indonesia \\ e-mail: mithasanthi90@gmail.com,arya sunu@yahoo.co.id, \\ mettasari 88@yahoo.com
}

\begin{abstract}
ABSTRAK
Penelitian ini bertujuan untuk mengetahui: (1) penerapan model pembelajaran berdasarkan masalah (PBI) dapat meningkatkan aktivitas dan hasil belajar Pkn siswa kelas VIIIA semester 2 SMP Negeri 1 Pekutatan tahun ajaran 2013/2014, (2) pendapat siswa terhadap penerapan model pembelajaran berdasarkan masalah (PBI) dalam pembelajaran Pkn. Penerapan model pembelajaran berbasis masalah dilaksanakan dalam bentuk Penelitian Tindakan Kelas. Subyek penelitiannya berjumlah 32 siswa. Objek penelitiannya adalah aktivitas belajar dan hasil belajar siswa. Penelitian ini dirancang dua siklus tindakan, dengan masing-masing 3 kali tatap muka. Adapun tahapan masing-masing siklusnya adalah perencanaan, pelaksanaan tindakan, observasi/evaluasi, dan refleksi. Data aktivitas belajar siswa dikumpulkan dengan pedoman observasi, sedangkan data hasil belajar siswa dikumpulkan dengan tes hasil belajar berbentuk pilihan ganda yang meliputi jenjang kognitif, aplikasi, analisis, sintesis, dan evaluasi. Data yang diperoleh dianalisis secara deskriptif kualitatif dan kuantitatif. Berdasarkan hasil analisis data dapat ditunjukkan bahwa aktivitas belajar PKn siswa terjadi peningkatan dengan rerataan sebesar 25,1 dikategorikan Aktif pada siklus I, menjadi 27,5 dikategorikan Sangat Aktif pada siklus II. Hasil belajar PKn siswa juga terjadi peningkatan dari siklus I ke siklus II, dengan rerata 73,3 dikategorikan Cukup menjadi 79,7 dikategorikan Baik. Perolehan nilai tertinggi 80 pada siklus I menjadi 90 pada siklus II. Perolehan nilai terendah 60 pada siklus I menjadi 65 pada siklus II. Daya serap siswa pada siklus I sebesar 73,3\% dikategorikan Kurang menjadi 79,7\% dikategorikan Baik pada siklus II. Ketuntasan belajar siswa secara klasikal pada siklus I sebesar 71,9\% dikategorikan Belum Tuntas, menjadi 96,9\% dikategorikan Tuntas pada siklus II.

Kata Kunci:, Model pembelajaran berdasarkan masalah, ,aktivitas belajar dan hasil belajar $P K n$.
\end{abstract}

\begin{abstract}
This study was aimed to determine: (1) the application of problem-based instruction (PBI) can increase the activity and students' learning result in civics lesson of $2^{\text {nd }}$ semester students in grade VIIIA at SMP Negerei 1 Pekutatan in the academic year 2013/2014, (2) the students opinion towards the implementation of problem-based instruction in civics learning. The implementation of problem-based instruction was implemented in the form of classroom action research. The subjects of this study were 32 students. The objects of this study are learning activities and students learning result. This study was designed into two cycles of action, with each of them consists of three meetings. The stages of each cycle were the planning, action, observation / evaluation, and reflection. The data of students learning activities were collected with observation guidelines, while the result of students learning data were collected with the achievement test in form of multiple choice which includes cognitive level, application, analysis, synthesis, and evaluation. Data were analyzed by descriptive qualitative and quantitative. Based on the analysis of data it can be shown that the activity of students in learning civics was increased with an average of 25.1 it can be categorized by active in cycle I, became 27.5 it can be categorized as Highly Active in the second cycle. The results of students learning in civics lesson also increased from the first cycle to the second cycle, with a mean of 73.3 it can be categorized as Enough became 79.7 it can be categorized as Good. The highest score on the
\end{abstract}


first cycle that is 80 became 90 on the second cycle. The lowest score on the first cycle that is 60 became 65 on the second cycle. Absorptive capacity of students on the first cycle was $73.3 \%$ it can be categorized as Less became $79.7 \%$ on the second cycle it can be categorized as Good. Students learning completeness classically on the first cycle was $71.9 \%$ it can be categorized as Incomplete, became $96.9 \%$ on the second cycle that can be categorized as Complete.

Keywords: Problem-based instruction, learning activities and Civics learning result.

\section{PENDAHULUAN}

Tujuan pendidikan nasional adalah untuk membentuk manusia Indonesia yang memiliki kemampuan ilmu pengetahuan serta teknologi dengan sikap serta perilaku yang sesuai dengan nilai-nilai bangsa Indonesia. Sebagaimana tercantum dalam Undang-Undang Nomor 20 Tahun 2003 tentang Sistem Pendidikan Nasional, yang menyatakan bahwa Pendidikan Nasional berfungsi mengembangkan kemampuan dan membentuk watak serta peradaban bangsa, bertujuan untuk berkembangnya potensi peserta didik agar menjadi manusia yang beriman, bertaqwa kepada Tuhan Yang Maha Esa, berakhlak mulia, sehat, berilmu, cakap, kreatif, mandiri dan menjadi warga Negara yang demokratis serta bertanggung jawab (Dirjen Pendidikan Nasional, 2006: 8-9).

Pendidikan merupakan media pembekalan pengetahuan, pengalaman, keterampilan, dan penguasaan teknologi bagi siswa untuk berkarya secara inovatif, kreatif dan tepat guna. Pendidikan juga sebagai media yang tepat untuk memperbaiki kualitas sumber daya manusia. Faktor yang meningkatkan keterampilan berpikir kritis adalah siswa lebih aktif dalam proses pembelajaran yang meliputi kegiatan bertanya, menjawab pertanyaan, dan mengemukakan pendapat. Peningkatan mutu pedidikan dapat dilakukan dengan menyiapkan guru, fasilitas dan sumber belajar yang memadai dari segi jumlah, jenis dan mutunya. Kemampuan guru merumuskan strategi belajar yang tepat akan sangat membantu ketercapaian tujuan belajar yang ingin dicapai. Sedangkan untuk membentuk warga negara yang baik mampu memahami, menghayati, serta mengamalkan hak dan kewajibannya maka dalam pendidikan formal di sekolah wajib diberikan Pendidikan Kewarganegaraan. Adapun Pendidikan Kewarganegaraan dimaksudkan adalah untuk membentuk peserta didik menjadi manusia yang memiliki rasa kebangsaan dan cinta tanah air (Anonim, 2003: 37). Dalam pelaksanaan program Pendidikan Kewarganegaraan di sekolah telah pula dilakukan langkah-langkah yang memungkinkan dapat terbinanya sikap dan prilaku yang sesuai dengan nilainilai yang terkandung dalam Pancasila dan Undang-Undang Dasar 1945. Harapan ini tertumpu pada salah satu Mata Pelajaran PKn yang memiliki tujuan utama untuk menumbuhkan wawasan dan kesadaran bernegara, serta membentuk sikap dan prilaku cinta tanah air yang bersendikan kebudayaan bangsa (Endang 2002: 2).

Berdasarkan pengertian di atas, maka mata pelajaran PKn memiliki arti penting dalam rangka pembinaan dan pembentukan manusia Indonesia yang berjiwa Pancasila khususnya bagi generasi muda penerus bangsa yang berada pada pendidikan dasar sampai pendidikan tinggi, dimana mereka mengemban tugas membina dan melestarikan nilai-nilai moral Pancasila.

Mengingat materi PKn mencakup penanaman sikap dan tingkah laku yang sesuai dengan nilai-nilai moral Pancasila dalam kehidupan sehari-hari maka dalam penyajian materi pembelajarannya diperlukan model pembelajaran yang sesuai dengan pokok bahasan, waktu dan tingkat kemampuan siswa. Keberhasilan pembelajaran sangat tergantung pada 
cara guru menggunakan model pembelajaran, sehingga memang benar kalau seorang guru memiliki andil yang sangat besar terhadap keberhasilan pembelajaran di sekolah. Tidak sedikit siswa kesulitan dalam mengikuti pelajaran dikarenakan model pembelajaran yang dipilih dan digunakan guru kurang tepat. Slameto, (1995: 64) menyatakan, metode mengajar guru yang kurang baik akan mempengaruhi aktivitas dan hasil belajar siswa yang kurang baik pula. Pemilihan model pembelajaran yang kurang baik dapat terjadi misalnya cara penyampaian materi atau metode pembelajaran kurang tepat dengan standar kompetensi dan kompetensi dasar yang dibahas, kurangnya persiapan dan penguasaan materi dari guru sehingga penyajian guru kurang jelas. Adanya indikasi seperti itu menyebabkan siswa menjadi kurang senang terhadap mata pelajaran yang diajarkan termasuk juga gurunya. Akibatnya siswa menjadi malas untuk belajar.

Pandangan siswa terhadap materi pelajaran terkadang dianggap sulit atau mudah karena dipengaruhi oleh pemilihan model dan gaya penampilan guru dalam proses pembelajaran. Oleh sebab itu, pembelajaran yang efisien yaitu pembelajaran yang menyenangkan, menggairahkan, penuh keakraban, sehingga menjadikan siswa belajar dengan betah dan bersemangat dalam memahami serta mempelajari semua jenis mata pelajaran yang diajarkan. Sehingga dalam melaksanakan pembelajaran guru dituntut memiliki kemampuan untuk melaksanakan perencanaan atau kesiapan yang matang. Guru harus mampu mendesain dan mengemas materi pelajaran sehingga mampu menarik perhatian serta minat siswa dalam pembelajaran. Dengan kata lain, guru harus mampu memilih model pembelajaran yang sesuai dengan materi pembelajaran yang akan dibahas sehingga minat serta perhatian siswa benar-benar terangsang untuk melaksanakan proses pembelajaran. Berdasarkan pandangan tersebut, dapat dipahami bahwa pemilihan dan penggunaan model pembelajaran oleh guru sangat berpengaruh terhadap kualitas pembelajaran di kelas dan selanjutnya proses pembelajaran sangat mempengaruhi aktivitas dan hasil belajar siswa.

Berdasarkan pengamatan yang dilakukan pada siswa kelas VIIIA SMP Negeri 1 Pekutatan, dimana penyajian materi pelajaran PKn dengan metode ceramah, menunjukkan aktivitas belajar siswa dalam mengikuti pelajaran $\mathrm{PKn}$ sangat rendah. Hal ini terbukti dari setiap guru menyajikan materi pelajaran PKn siswa kurang berminat, siswa terlihat acuh tak acuh, siswa sering mengalihkan perhatian pada pelajaran lain, bahkan tidak jarang siswa tertidur pada saat pelajaran berlangsung. Kondisi ini disebabkan karena kurang menariknya guru PKn dalam menerapkan model dan strategi dalam pembelajaran PKn.

Sehubungan dengan permasalahan di atas, maka upaya peningkatan kualitas belajar mengajar pada mata pelajaran PKn merupakan suatu kebutuhan yang cukup baik untuk dilakukan. Salah satu model pembelajaran yang dapat menjembatani kesusahan belajar siswa dan salah satu model pembelajaran yang berpihak kepada siswa dan dapat dikembangkan oleh guru dalam proses pembelajaran di kelas adalah model pembelajaran berdasarkan masalah atau dalam bahasa inggrisnya disebut dengan model pembelajaran Problem Based Instruction (PBI). PBI merupakan suatu model pembelajaran yang didasarkan pada banyaknya permasalahan yang membutuhkan penyelidikan autentik yakni penyelidikan yang membutuhkan penyelesaian nyata dari permasalahan yang nyata.

Model pembelajaran berdasarkan masalah (PBI) melatih peserta didik menyusun sendiri pengetahuannya, mengembangkan keterampilan 
pemecahan masalah secara mandiri, serta dapat meningkatkan kepercayaan diri. Sehingga melalui penerapan model pembelajaran berdasarkan masalah dalam materi pelajaran $\mathrm{PKn}$, berpotensi meningkatkan aktivitas dan hasil belajar siswa. Aktivitas dalam model pembelajaran berdasarkan masalah lebih didominasi oleh kegiatan siswa (student center), sedangkan guru cendrung sebagai fasilitator, mediator, motivator, konsultan, dan pendengar yang empati. Siswa belajar mulai dari mencari pengetahuan yang relevan, merancang penyelidikan atau percobaan, mengamati, mengumpulkan dan menganalisis data hasil penelitian, memecahkan masalah yang ditemukan dalam kehidupan sehari-hari, dan mengkomunikasikan pengetahuan yang diperolehnya. Akibatnya, keterampilan berpikir kritis dan pemahaman konsep siswa dalam pembelajaran PKn dapat ditingkatkan

Bertolak dari kajian di atas, maka penelitian ini akan memfokuskan kajian pada "Implementasi Model Pembelajaran Berdasarkan Masalah (Problem Based Instruction) untuk Meningkatkan Aktivitas dan Hasil Belajar PKn Siswa Kelas VIIIA Semester 2 SMP Negeri 1 Pekutatan Tahun Pelajaran 2013/2014". Untuk mendukung hal tersebut, maka penelitian ini diarahkan melalui serangkaian tindakan yang terencana dan terprogram dalam dimensi Penelitian Tindakan Kelas (Classroom Action Research), terutama dalam hal ini untuk mengatasi beberapa masalah yang dihadapi dalam pembelajaran PKn di SMP Negeri 1 Pekutatan, khususnya pada kelas VIIIA.

Rendahnya proses dan hasil pembelajaran PKn dilihat dari persepektif didaktik metodik disinyalir disebabkan oleh beberapa faktor, baik yang bersifat internal maupun eksternal. Menurut Hasan (1996), kualitas proses dan produk pembelajaran dalam praktek pendidikan di Indonesia banyak dipengaruhi oleh kinerja guru dan kinerja siswa. Disamping itu, ketersediaan sarana dan prasarana pembelajaran, fasilitas kurikulum, komitmen para perencana dan praktisi pendidikan, lingkungan sosial budaya, dan komitmen politik penguasa, merupakan faktor-faktor yang memiliki intensitas pengaruh yang tidak jauh berbeda dengan dua faktor utama di atas.

Pamuji (1994), menyatakan bahwa faktor-faktor internal yang secara langsung mempengaruhi kualitas pembelajaran dapat dibagi menjadi dua bagian yaitu, faktor guru dan faktor siswa. Sementara itu faktor-faktor eksternalnya dapat berupa daya dukung lingkungan, peralatan, dan komitmen serta iklim kerja lingkungan sekolah itu sendiri. Belum efektifnya proses pembelajaran di SMP Negeri 1 Pekutatan, hal ini dikarenakan kegiatan belajar mengajar yang selama ini berlangsung masih menggunakan model pembelajaran yang bersifat konvensional yaitu metode ceramah.

Berdasarkan beberapa teori dan pendapat di atas dapat diinterpretasikan bahwa banyak faktor yang berinteraksi dan menyebabkan rendahnya kualitas proses dan produk pembelajaran. Hasil observasi awal peneliti dengan guru-guru PKn yang mengajar di SMP Negeri 1 Pekutatan, ditemukan beberapa hal yang menyebabkan rendahnya hasil belajar PKn pada siswa kelas VIII, antara lain: 1) kemampuan dan pengetahuan awal siswa relatif kurang, terlihat dari rendahnya rerata nilai hasil ujian akhir, 2) siswa relatif sulit memahami konsep yang bersifat abstrak, karena kemampuan analisisnya rata-rata relatif rendah, 3) siswa tidak banyak yang mempersiapkan diri sebelum pembelajaran dimulai, walaupun materi yang akan dibahas sudah diinformasikan sebelumnya, 4) aktivitas siswa dalam proses pembelajaran sangat rendah, dan hanya didominasi oleh siswa yang pintar saja, dan 5) siswa belum mampu menyelesaikan 
permasalahan yang berkaitan langsung dengan kehidupan nyata sehari-hari.

Dari faktor-faktor yang telah dikemukakan di atas, muncul berbagai permasalahan yang sekiranya perlu dicarikan solusinya, diantaranya: 1) model pembelajaran bagaimanakah yang dapat meningkatkan hasil belajar dan aktivitas belajar siswa dalam pembelajaran PKn?; 2) mengapa model pembelajaran PKn yang selama ini diterapkan oleh guru belum efektif meningkatkan hasil belajar siswa?; 3) apakah hasil belajar berpengaruh terhadap aktivitas belajar siswa?

\section{METODE}

Penelitian ini merupakan Penelitian Tindakan Kelas (Classroom Action Research) yang dilaksanakan pada kelas VIIIA semester 2 SMP Negeri 1 Pekutatan tahun pelajaran 2013/2014. Penelitian ini dilaksanakan materi tentang Standar Kompetensi, yaitu memahami pelaksanaan demokrasi dalam berbagai aspek kehidupan. Sedangkan Kompetensi Dasar yang dijadikan kajian penelitian, yaitu 1) menjelaskan hakikat demokrasi dan 2) menjelaskan pentingnya kehidupan demokrasi dalam bermasyarakat, berbangsa, dan bernegara. Subyek adalah siswa kelas VIIIA yang berjumlah 32 orang dengan rincian lakilaki 6 orang dan perempuan 26 orang dan obyek dari penelitian ini adalah aktivitas belajar dan hasil belajar PKn siswa akibat penerapan pembelajaran berdasarkan masalah (PBI). Penelitian ini dirancang dua siklus tindakan, dengan masing-masing 3 kali tatap muka. Adapun tahapan masing-masing siklusnya adalah perencanaan, pelaksanaan tindakan, observasi/evaluasi, dan refleksi. Data aktivitas belajar siswa dikumpulkan dengan pedoman observasi, sedangkan data hasil belajar siswa dikumpulkan dengan tes hasil belajar berbentuk pilihan ganda yang meliputi jenjang kognitif, aplikasi, analisis, sintesis, dan evaluasi. Data yang diperoleh dianalisis secara deskriptif kualitatif dan kuantitatif

\section{HASIL PENELITIAN DAN PEMBAHASAN HASIL PENELITIAN}

Hasil tindakan siklus I yang sekaligus merupakan objek dari penelitian ini, meliputi aktivitas belajar siswa dan hasil belajar PKn siswa. Data aktivitas belajar siswa diperoleh dari hasil observasi, sedangkan data hasil belajar siswa diperoleh dengan melakukan pemberian tes hasil belajar kepada siswa.

1. Aktivitas Belajar Siswa Siklus I

Berdasarkan hasil observasi siklus I untuk tiga kali tatap muka, didapatkan data tentang aktivitas belajar siswa, yang selanjtunya dirangkum, seperti pada Tabel 4.1 dan rentangan skor dan kualifikasi aktivitas belajar siswa pada Tabel $4.2 \quad$ berikut.

Tabel 4.1 Data Aktivitas Belajar Siswa Siklus I

\begin{tabular}{|l|l|l|l|}
\hline No & Data Aktivitas Belajar Siswa & Total & Kategori \\
\hline 1 & Skor aktivitas belajar & 803 & \\
\hline 2 & Rerata aktivitas belajar & 25,1 & Aktif \\
\hline 3 & Skor tertinggi & 29 & \\
\hline 4 & Skor terendah & 21 & \\
\hline
\end{tabular}

Tabel 4.2 Rentangan Skor dan Jenjang Klasifikasi

\begin{tabular}{|l|l|}
\hline Rentang Skor & Klasifikasi/ Predikat \\
\hline $26 \leq \bar{X}$ & Sangat Aktif \\
\hline $24,7 \leq \bar{X} \leq 26$ & Aktif \\
\hline
\end{tabular}




\begin{tabular}{|l|l|}
\hline $23,3 \leq \bar{X} \leq 24,7$ & Cukup Aktif \\
\hline $22 \leq \bar{X} \leq 23,3$ & Tidak Aktif \\
\hline $\bar{X} \leq 22$ & Sangat Tidak Aktif \\
\hline
\end{tabular}

Berdasarkan hasil observasi dan evaluasi yang dilakukan pada siklus I maka dapat dijelaskan bahwa, aktivitas belajar siswa berlangsung dengan baik. Berdasarkan Tabel 4.1, tentang data aktivitas belajar siswa siklus I dapat dijelaskan bahwa nilai rata-rata aktivitas belajar siswa pada pelaksanaan siklus I sebesar 25,1. Untuk nilai tertinggi siswa sebesar 29 dan nilai terendah sebesar 21. Mengacu pada Tabel 4.2 tentang rentangan skor dan jenjang klasifikasi, maka nilai rata-rata aktivitas belajar siswa kelas VIIIA pada pelaksanaan siklus I berada pada kualifikasi nilai dengan kategori Aktif. Secara detail perhitungan aktivitas belajar siswa siklus I dapat dilihat pada Lampiran 10.

\section{Hasil Belajar Siswa Siklus I}

Data mengenai hasil belajar siswa dikumpulkan dengan menggunakan tes hasil belajar. Secara ringkas hasil belajar siswa dapat dilihat seperti pada Tabel $4.3 \quad$ berikut

Tabel 4.3 Data Tes Hasil Belajar Siswa Siklus I

\begin{tabular}{|l|l|l|}
\hline Keterangan & Hasil Belajar Siswa & Kategori \\
\hline Rerata hasil belajar & 73,3 & Cukup \\
\hline Nilai Tertinggi & 80 & \\
\hline Nilai Terendah & 60 & \\
\hline Ketuntasan Individual & & \\
1. Tuntas (23 orang) & $71,9 \%$ & \\
2. Tidak Tuntas (9 orang) & $28,1 \%$ & Kurang \\
\hline Daya Serap & $73,3 \%$ & Belum Tuntas \\
\hline Ketuntasan Klasikal & $71,9 \%$ & \\
\hline
\end{tabular}

Sesuai dengan data pada Tabel 4.3 di atas, maka dapat dijelaskan hasil belajar siswa pada siklus I, tergolong Cukup, yaitu dengan rerata nilai 73,3 . Ketuntasan belajar secara klasikal (\% siswa yang skornya $\leq 85 \%$ ) mencapai $71,9 \%$ atau dengan kategori Belum Tuntas, yang masih jauh dari kriteria keberhasilan yang ditetapkan, yaitu sebesar $85 \%$. Sedangkan daya serap mencapai $73,3 \%$ dan dinyatakan dalam kategori Kurang. Secara detail perhitungan hasil belajar siswa siklus I dapat dilihat pada Lampiran 7.

\section{Refleksi siklus I}

Penerapan model pembelajaran berdasarkan masalah pada mata pelajaran PKn untuk bahan kajian tentang menjelaskan hakikat demokrasi, belum berlangsung dengan baik. Banyak dikalangan siswa yang terkejut dengan penerapan model tersebut, ini dapat dibuktikan dari adanya kebingungan sebagian siswa terhadap tugas-tugas yang harus dilakukan. Namun, dengan selalu memberikan bimbingan dalam kegiatan pembelajaran tersebut, kekurangan itu mulai dapat direduksi secara perlahan.

Mulai tatap muka kedua, penerapan model ini sudah mendapat respon cukup positif oleh siswa. Namun, secara umum aktivitas belajar siswa belum berlangsung dengan baik, dalam hal ini interaksi siswa dalam pembelajaran belum terlihat dengan optimal. Hal ini menyebabkan banyak permasalahan belum dapat diselesaikan dengan efektif dan efesien. Terdapat kesan, siswa terkejut dengan penerapan model pembelajaran yang tergolong baru 
tersebut. Keterkejutan ini berdampak secara psikologis terhadap aktivitas siswa belajar.

Hasil belajar siswa berkaitan dengan materi yang dikaji berkategori Cukup. Hal ini dapat dilihat dari perolehan rerata nilai 73,3 , dengan ketuntasan belajar secara klasikal $71,9 \%$. Hasil ini menunjukkan bahwa ketuntasan secara klasikal belum tercapai, yaitu minimal sebesar $85 \%$. Demikian pula halnya dengan rerata perolehan nilai yang baru mencapai 73,3 belum mencapai kriteria keberhasil yang telah ditetapkan, yaitu sebesar 75 . Perolehan hasil ini, tidak terlepas dari penerapan model pembelajaran yang relatif baru, serta tuntutan hasil belajar yang lebih tinggi, karena menyangkut pemahaman secara komprehensif. Faktor lain yang juga berpengaruh terhadap hasil tersebut adalah tingkat kognitif tes yang meliputi aplikasi, analisis, sintesis, dan evaluasi yang menuntut siswa berpikir tingkat tinggi. Oleh karena itu, diperlukan strategi yang lebih efektif dan efisien dalam rangka meningkatkan minat dan motivasi belajar.

Hasil tindakan siklus II, meliputi aktivitas belajar siswa, dan hasil belajar PKn siswa dengan penerapan model pembelajaran berdasarkan masalah (PBI).

1. Aktivitas Belajar Siswa Siklus II

Hasil observasi tentang aktivitas belajar siswa siklus II dilakukan pada pembelajaran materi pokok menjelaskan pentingnya kehidupan demokrasi dalam bermasyarakat, berbangsa, dan bernegara, untuk tiga kali tatap muka. Berdasarkan data hasil observasi terhadap aktivitas belajar siswa tersebut, dapat dijelaskan bahwa selama pembelajaran siklus II menunjukkan aktivitas belajar siswa berlangsung dengan sangat baik. Semua indikator (parameter) aktivitas belajar menunjukkan kategori baik. Hasil observasi dan evaluasi pada siklus II terhadap aktivitas belajar siswa pada ke-8 parameter aktivitas belajar, disajikan dalam Tabel 4.4 berikut

Tabel 4.4 Data Aktivitas Belajar Siswa Siklus II

\begin{tabular}{|l|l|l|l|}
\hline No & Data Aktivitas Belajar Siswa & Total & Kategori \\
\hline 1 & Skor aktivitas belajar & 879 & \\
\hline 2 & Rerata aktivitas belajar & 27,469 & Sangat Aktif \\
\hline 3 & Skor tertinggi & 32 & \\
\hline 4 & Skor terendah & 24 & \\
\hline
\end{tabular}

Tabel 4.5 Rentangan Skor dan Jenjang Klasifikasi

\begin{tabular}{|l|l|}
\hline Rentang Skor & Klasifikasi/ Predikat \\
\hline $26 \leq \bar{X}$ & Sangat Aktif \\
\hline $24,7 \leq \bar{X} \leq 26$ & Aktif \\
\hline $23,3 \leq \bar{X} \leq 24,7$ & Cukup Aktif \\
\hline $22 \leq \bar{X} \leq 23,3$ & Tidak Aktif \\
\hline $\bar{X} \leq 22$ & Sangat Tidak Aktif \\
\hline
\end{tabular}

Berdasarkan hasil observasi dan evaluasi yang telah dilakukan dapat dijelaskan bahwa aktivitas belajar siswa berlangsung dengan sangat baik. Berdasarkan Tabel 4.4, tentang data aktivitas belajar siswa siklus II dapat dijelaskan bahwa nilai rata-rata aktivitas belajar siswa pada pelaksanaan siklus
II sebesar 27,5. Untuk nilai tertinggi siswa sebesar 32 dan nilai terendah sebesar 24. Mengacu pada Tabel 4.5 (rentangan skor dan jenjang klasifikasi), maka nilai rata-rata aktivitas belajar siswa kelas VIIIA pada pelaksanaan siklus II berada pada kualifikasi nilai dengan kategori Sangat Aktif. Secara 
detail perhitungan aktivitas belajar siswa siklus II dapat dilihat pada Lampiran 10.

2. Hasil Belajar Siswa Siklus II
Data mengenai hasil belajar siswa siklus II, juga dikumpulkan dengan menggunakan tes hasil belajar. Adapun hasil yang diperoleh disajikan pada Tabel 4.6 berikut.

Tabel 4.6Hasil Belajar Siswa Siklus II

\begin{tabular}{|l|l|l|}
\hline Keterangan & Hasil Belajar Siswa & Kategori \\
\hline Rerata hasil belajar & 79.7 & Baik \\
\hline Nilai Tertinggi & 90 & \\
\hline Nilai Terendah & 65 & \\
\hline Ketuntasan Individual & & \\
1. Tuntas (31 orang) & $96,9 \%$ & \\
2. Tidak Tuntas (1 orang) & $3,1 \%$ & Baik \\
\hline Daya Serap & $79,7 \%$ & Tuntas \\
\hline Ketuntasan Klasikal & $96,9 \%$ & \\
\hline
\end{tabular}

Sesuai dengan data tentang hasi belajar pada Tabel 4.6 di atas, maka dapat dijelaskan hasil belajar siswa pada siklus II, tergolong Baik, yaitu dengan rerata nilai 79,7 . Ketuntasan belajar secara klasikal (\% siswa yang skornya $\leq 85 \%$ ) mencapai $96,9 \%$ atau dengan kategori Tuntas, dengan ketentuan bahwa hasil belajar siswa melebihi kriteria keberhasilan yang ditetapkan, yaitu sebesar $85 \%$. Sedangkan daya serap mencapai $79,7 \%$ dan dinyatakan dalam kategori Baik. Secara detail perhitungan hasil belajar siswa siklus II dapat dilihat pada Lampiran 8.

\section{Refleksi Siklus II}

Setelah

dilakukan

penyempurnaan terhadap penerapan model pembelajaran berdasarkan masalah (PBI) pada mata pelajaran PKn, maka terdapat kecendrungan peningkatan kualitas proses dan hasil belajar siswa. Pada pembahasan materi pokok tentang menjelaskan pentingnya kehidupan demokrasi dalam bermasyarakat, berbangsa, dan bernegara, siswa sangat aktif berdiskusi, mencari informasi, bahkan berani bertanya kepada guru PKn lainnya. Ini menunjukkan keterlibatan siswa dalam pembelajaran sangat tinggi. Siswa tidak terjebak pada buku pendukung saja dalam mencari dan menggali informasi, tetapi sudah menggunakan sumber belajar yang lainnya, seperti media masa, ensiklopedi, dan nara sumber lainnya. Keberanian siswa mulai tumbuh, ini dapat dilihat dari meningkatnya jumlah siswa yang berani bertanya kepada teman sebaya dan guru.

Ditinjau dari perolehan rerata hasil belajar siswa, dapat dijelaskan bahwa ada peningkatan dibandingkan dengan siklus I. Rerata hasil belajar untuk materi pokok menjelaskan pentingnya kehidupan demokrasi dalam bermasyarakat, berbangsa, dan bernegara pada siklus II mencapai 79,7 , telah melewati KKM yang ditetapkan, yaitu sebesar 75 . Ini berarti penerapan model pembelajaran berdasarkan masalah (PBI) pada mata pelajaran $\mathrm{PKn}$ relatif efektif dalam meningkatkan hasil belajar siswa. Ketuntasan belajar juga dapat ditingkatkan dari $71,9 \%$ pada siklus I, dengan kategori Belum Tuntas menjadi 96,9\% pada siklus II, dengan kategori Tuntas. Hasil ini menunjukkan bahwa ketuntasan secara klasikal dapat tercapai, yaitu minimal sebesar $85 \%$. Perolehan hasil ini, tidak terlepas dari penerapan model pembelajaran berdasarkan masalah (PBI) yang diterapkan dalam pembelajaran PKn.

Secara ringkas perbandingan data aktivitas belajar siswa pada siklus 
Tabel 4.7 Perbandingan Data Aktivitas Belajar Siswa Siklus I dan Siklus II

\begin{tabular}{|l|l|l|l|l|l|}
\hline \multirow{2}{*}{ No } & \multirow{2}{*}{$\begin{array}{l}\text { Data Aktivitas Belajar } \\
\text { Siswa }\end{array}$} & \multicolumn{2}{|l|}{ Siklus I } & \multicolumn{2}{l|}{ Siklus II } \\
\cline { 3 - 6 } & & Total & Kategori & Total & Kategori \\
\hline 1 & Skor aktivitas belajar & 803 & & 879 & \\
\hline 2 & Rerata aktivitas belajar & 25,1 & Aktif & 27,5 & Sangat Aktif \\
\hline 3 & Skor tertinggi & 29 & & 32 & \\
\hline 4 & Skor terendah & 21 & & 24 & \\
\hline
\end{tabular}

Dari data perbandingan aktivitas belajar siswa seperti pada Tabel $4.7 \mathrm{di}$ atas, dapat disimpulkan bahwa terjadi peningkatan aktivitas siswa dari siklus I dengan rerataan sebesar 25,1 (Aktif) dibandingkan rerataan siklus II sebesar 27,5 (Sangat Aktif). Secara detail perhitungan aktivitas belajar siswa siklus I dan siklus II dapat dilihat pada Lampiran 9 dan Lampiran 10.

Sedangkan perbandingan hasil belajar siswa pada siklus I dan Siklus II dapat dilihat pada Tabel 4.8 berikut.

Tabel 4.8 Perbandingan Skor Hasil Belajar Siswa Siklus I dan Siklus II

\begin{tabular}{|c|c|c|c|c|}
\hline \multirow{2}{*}{ Keterangan } & \multicolumn{4}{|c|}{ Hasil Belajar Siswa } \\
\hline & Siklus I & Kategori & Siklus II & Kategori \\
\hline Rerata hasil belajar & 73,3 & Cukup & 79.7 & Baik \\
\hline Nilai Tertinggi & 80 & & 90 & \\
\hline Nilai Terendah & 60 & & 65 & \\
\hline $\begin{array}{l}\text { Ketuntasan Individual } \\
\text { 1. Tuntas } \\
\text { 2. Tidak Tuntas }\end{array}$ & $\begin{array}{l}23 \text { (orang) } \\
71,9 \% \\
9 \quad \text { (orang) } \\
28,1 \%\end{array}$ & & $\begin{array}{l}31 \quad \text { (orang) } \\
96,9 \% \\
1 \text { (orang) } \\
3,1 \%\end{array}$ & \\
\hline Daya Serap & $73,3 \%$ & Kurang & $79,7 \%$ & Baik \\
\hline Ketuntasan Klasikal & $71,9 \%$ & $\begin{array}{l}\text { Belum } \\
\text { Tuntas }\end{array}$ & $96,9 \%$ & Tuntas \\
\hline
\end{tabular}

Berdasarkan data perbandingan hasil belajar siswa seperti pada Tabel 4.8 di atas, dapat disimpulkan bahwa terdapat peningkatan pencapaian hasil belajar siswa dari siklus I ke siklus II. Peningkatan itu, terjadi pada perolehan rerata nilai, yaitu dari 73,3 dengan kategori Cukup pada siklus I, menjadi 79,7 dengan kategori Baik pada siklus II. Perolehan nilai tertinggi dari 80 pada siklus I menjadi 90 pada siklus II. Perolehan nilai terendah dari 60 pada siklus I menjadi 65 pada siklus II.

Dilihat dari persentase daya serap dan ketuntasan siswa secara klasikal juga terjadi peningkatan. Untuk daya serap siswa terhadap materi pada siklus I sebesar $73,3 \%$ dengan kategori Kurang dan daya serap siswa terhadap materi pada siklus II sebesar $79,7 \%$ dengan kategori Baik. Dengan kriteria keberhasilan tindakan tiap siklusnya yaitu jika Daya Serap Siswa (DSS) $\geq$ $75 \%$.

Sedangkan untuk ketuntasan siswa secara klasikal pada siklus I sebesar 71,9\% dikategorikan Belum Tuntas, dan terjadi peningkatan pada siklus II sebesar 96,9\% dikategorikan Tuntas. Dengan kriteria keberhasilan tindakan setiap siklusnya yaitu jika Ketuntasan Klasikal (KK) $\geq 85 \%$. Secara detail perhitungan hasil belajar 
siswa siklus I dan siklus II dapat dilihat pada Lampiran 7 dan Lampiran 8.

\section{Pembahasan}

Penerapan model pembelajaran berdasarkan masalah (PBI), mendapat respon yang postif dari siswa. Hal ini dapat dilihat dari aktivitas belajar siswa dan hasil belajar siswa yang cendrung mengalami peningkatan dari siklus I ke siklus II. Aktivitas siswa belajar pada siklus I, belum berlangsung dengan baik, sehingga masih perlu ditingkatkan. Pada siklus I, siswa yang bertanya maupun menjawab pertanyaan masih sedikit dan didominasi oleh siswa yang pintar saja. Suasana kelas terlihat tegang sehingga hubungan siswa dengan siswa dan siswa dengan guru terkesan kaku. Hal ini disebabkan karena siswa kelas VIIIA masih menganggap pembelajaran PKn membosankan dan kurang menarik, disamping itu karena siswanya juga memang malas. Beberapa umpan balik guru belum mendapatkan tanggapan yang memuaskan.

Aktivitas belajar siswa pada siklus II mengalami peningkatan dibandingkan siklus I. Interaksi belajar siswa sangat dinamis dan kerjasama antar siswa baik dalam kelompok maupun antar kelompok berlangsung dengan baik. Jumlah siswa yang berani bertanya meningkat serta mulai ada siswa yang menanggapi pertanyaan dari siswa atau guru. Bahkan ada kecendrungan pertanyaan yang diajukan mengarah kepada kehidupan nyata sehari-hari (kontekstual). Peningkatan tersebut secara langsung maupun tidak langsung berdampak terhadap kemampuan intelektual siswa.

$\mathrm{Hal}$ ini terjadi karena beberapa faktor, yaitu: 1) siswa telah mempunyai pengalaman mengikuti pembelajaran dengan penerapan model pembelajaran berdasarkan masalah (PBI) pada siklus I sehingga siswa sudah mampu beradaptasi dengan suasana pembelajaran, 2) adanya informasi mengenai penjelasan teknis serta kelemahan-kelemahan siswa dalam mengikuti pembelajaran oleh guru, menyebabkan siswa menerapkan strategi tertentu sebagai bentuk antisipasi, 3) penyampaian hasil belajar siswa baik secara individual maupun kelompok, menimbulkan rasa "jengah", untuk berkompetisi dalam memperoleh hasil belajar yang lebih baik, dan 4) pemanfaatan sumber belajar yang lebih variatif, seperti software pembelajaran, perpustakaan, kantor desa/ kecamatan, dan nara sumber lainnya yang relevan, meningkatkan motivasi dan keingintahuan siswa untuk mengikuti pembelajaran.

Hasil belajar siswa pada siklus I tentang menjelaskan hakikat demokrasi berkategori cukup dengan rerata nilai 73,3. Namun, hasil ini belum memenuhi kriteria keberhasilan yang telah ditetapkan sebesar 75 sesuai dengan kriteria ketuntasan minimal yang ditetapkan di SMP Negeri 1 Pekutatan. Masih rendahnya perolehan hasil belajar siswa disebabkan beberapa faktor, diantaranya; 1) jenis tes yang dikembangkan berada pada jenjang kognitif tinggi, sehingga siswa kesulitan dan kehabisan waktu untuk menyelesaiakannya, 2) siswa belum mempunyai pengalaman untuk menjawab soal uraian terbuka yang open ended, karena adanya kebiasaan menjawab soal pilihan ganda, dan 3) pengetahuan awal siswa yang rendah, ini dapat dilihat dari rerata nilai $\mathrm{PKn}$ siswa pada hasil nilai TPA.

Rendahnya pengetahuan awal siswa merupakan salah satu faktor yang menentukan aktivitas dan hasil belajar siswa. Dengan demikian pengetahuan awal merupakan informasi sebagai bahan refleksi bagi guru untuk merencanakan strategi pembelajaran. Hal ini karena salah satu indikator kualitas proses pembelajaran adalah mengaitkan pengetahuan awal yang dimiliki siswa dengan bahan kajian yang akan dibahas (Depdiknas, 2002).

Akibat pengetahuan awal siswa yang masih rendah maka perlu direncanakan pembelajaran yang memberikan pengalaman konkrit 
kepada siswa. Salah satu diantaranya adalah dengan menerapakan model pembelajaran berdasarkan masalah (PBI). Masalah yang dipecahkan adalah masalah yang sering ditemukan dalam kehidupan nyata sehari-hari. Melalui penerapan model pembelajaran ini, siswa dapat mengikuti prosedur pembelajaran yang bermakna, dan mengandung langkah-langkah mengamati, melakukan, dan menginterpretasi data hasil pengamatan. Hal ini sesuai dengan yang disebutkan oleh Edgar Dale bahwa pengalaman belajar yang paling tinggi tingkatannya adalah pengalaman belajar konkret. Sedangkan yang paling rendah adalah pengalaman belajar abstrak (Ali, 2000).

Hasil belajar siswa pada siklus II cenderung mengalami peningkatan dibandingkan siklus I. Rerata skor hasil belajar pada silkus II mencapai 79,7, dengan ketuntasan belajar mencapai $96,9 \%$ dari $85 \%$ batasan minimal ketuntasan belajar siswa secara klasikal.

Penerapan model pembelajaran berdasarkan masalah (PBI) dalam pembelajaran PKn, secara umum direspon positif oleh siswa. Hal ini terlihat dari kesungguhan dan kehadiran siswa mengikuti pembelajaran. Penerapan model pembelajaran berdasarkan masalah (PBI) mampu meningkatkan motivasi dan minat siswa untuk belajar lebih baik. Ini sesuai dengan pendapat Jordan E Ayan (2002) yang menyatakan bahwa dalam proses pembelajaran, cara dan gaya baru yang disajikan kepada siswa, pada umumnya menimbulkan rasa ingin tahu siswa. Rasa ingin tahu mendorong seseorang untuk menyelidiki bidang baru atau mencari cara mengerjakan sesuatu dengan lebih baik.

Penerapan model pembelajaran berdasarkan masalah (PBI) juga dapat mengoptimalkan pengalaman belajar, seperti pengalaman mengamati, mencatat data, dan melakukan kajian literatur, dan mengkomunikasikan pengetahuan. Keadaan ini mendorong aksi dan refleksi pada siswa, untuk segera tanggap dengan situasi pembelajaran yang baru. Pembelajaran yang melibatkan seluruh indera akan lebih bermakna dibandingkan dengan satu indera saja (Dryden, G. dan Vos, J., 2002).

\section{SIMPULAN}

Berdasarkan hasil penelitian dan pembahasan yang telah dijelaskan di atas, maka dapat disimpulkan bahwa:

1. Penerapan model pembelajaran berdasarkan masalah (Problem Based Introduction) dapat meningkatkan aktivitas belajar PKn siswa kelas VIIIA semester 2 SMP Negeri 1 Pekutatan tahun pelajaran 2013/2014. Peryataan ini dikuatkan dengan adanya temuan bahwa, terjadi peningkatan rerataan aktivitas belajar siswa pada siklus I sebesar 25,1 dengan kategori Aktif, dibandingkan rerataan siklus II sebesar 27,5 dengan kategori Sangat Aktif. Selain itu, juga terjadi peningkatan skor yang diperoleh siswa, dimana pada siklus I skor tertinggi sebesar 29 dan skor terendahnya 21 , sedangkan pada siklus II skor tertinggi yang diperoleh siswa sebesar 32 dan skor terendahnya 24.

2. Penerapan model pembelajaran berdasarkan masalah (Problem Based Introduction) dapat meningkatkan hasil belajar PKn siswa kelas VIIIA Semester 2 SMP Negeri 1 Pekutatan Tahun Pelajaran 2013/2014. Peryataan ini dikuatkan dengan adanya temuan bahwa, terjadi peningkatan pencapaian hasil belajar siswa dari siklus I ke siklus II. Peningkatan itu, terjadi pada perolehan rerata nilai, yaitu dari 73,3 dengan kategori Cukup pada siklus I, menjadi 79,7 dengan kategori Baik pada siklus II. Perolehan nilai tertinggi dari 80 pada siklus I menjadi 90 pada siklus II. Perolehan nilai terendah dari 60 pada siklus I menjadi 65 pada siklus II. Untuk 
daya serap siswa terhadap materi pada siklus I sebesar $73,3 \%$ dengan kategori Kurang dan daya serap siswa terhadap materi pada siklus II sebesar $79,7 \%$ dengan kategori Baik. Dengan kriteria keberhasilan tindakan tiap siklusnya yaitu jika Daya Serap Siswa (DSS) $\geq 75 \%$. Sedangkan untuk ketuntasan siswa secara klasikal pada siklus I sebesar $71,9 \%$ dikategorikan Belum Tuntas, dan terjadi peningkatan pada siklus II sebesar 96,9\% dikategorikan Tuntas. Dengan kriteria keberhasilan tindakan setiap siklusnya yaitu jika Ketuntasan Klasikal $(\mathrm{KK}) \geq 85 \%$.

\section{SARAN}

1. Pembelajaran PKn dengan model pembelajaran berdasarkan masalah (PBI) dapat meningkatkan aktivitas belajar siswa dan hasil belajar siswa sehingga disarankan agar guru-guru dapat menerapkan dan mengembangkannya sesuai dengan situasi dan kondisi di sekolah;

2. Dalam merancang model pembelajaran PKn dengan model pembelajaran berdasarkan masalah (PBI) pada mata pelajaran PKn, disarankan agar materi, alat, dan bahan yang dijadikan sebagai pendukung KBM faktual, aktual mudah didapat, murah, dan ada di lingkungan siswa atau sekolah sehingga pembelajaran menjadi konkrit, aplikatif, dan kontekstual.

3. Disarankan kepada guru-guru pada umumnya, dan guru PKn khususnya, agar terus melakukan inovasi model pembelajaran sehingga dapat meningkatkan kualitas proses dan hasil belajar.

\section{DAFTAR PUSTAKA}

Adnyana, dkk. 2008. Meningkatkan Aktivitas Belajar, Keterampilan Berpikir Kritis, dan Pemahaman Konsep PKn Siswa Melalui Penerapan Model Pembelajaran Berdasarkan masalah. Buleleng. Laporan penelitian Anggaran DIPA
Direktorat Jenderal Peningkatan Mutu Pendidik dan Tenaga Kependidikan, Departemen Pendidikan Nasional.

Ali, M. H. 2000. Guru Dalam Proses Belajar Mengajar. Cetakan ke-10. Bandung: PT Sinar Baru Algensindo.

Arends, R. I. 2004. Learning To Teach. Sixth Edition. New York. McGrawHill Co. Inc.

Arikunto, Suharsimi. 2005. Penelitian Tindakan Kelas. Yogyakarta. Materi Diklat.

Ayan, J. E. 2002. Bengkel Kreativitas: 10 Cara Menemukan Ide-ide Pamungkas. Penerjemah Ibnu Setiawan. Aha!: 10 Ways to Free Your Creative Spirit and Find Your Great Ideas Bibliografi. 1997. Bandung: Kaifa

Bachman, E. 2005. Metode Belajar Berpikir Kritis dan Inovatif. Terjemahan Bahrul Ulum. Creative Thinking Roadmap. Jakarta: PT. Prestasi Pustaka Raya.

BSNP. 2006. Standar Kompetensi dan Kompetensi Dasar Untuk SMP Kurikulum Tingkat Satuan Pendidikan Jenjang Pendidikan Dasar dan Menengah. Jakarta.

BSNP. 2007. Model Penilaian Kelas Kurikulum Berbasis Kompetensi SMP. Jakarta: Ditjen Manajemen Dikdasmen, Depdiknas.

Costa, A. L. (ed). 1988. Developing Minds: A Resource Book For Teaching Thinking. Virginia: ASCD.

De.Porter, dkk, B. (2000). Quantum Teaching. Bandung: Kaifa.

Depdiknas. 2002. Kurikulum Berbasis Kompetensi. Jakarta: Puskur, Balitbang Depdiknas.

Depdiknas. 2003. Penilaian Tingkat Kelas: Pedoman Bagi Guru SD/MI, SMP/MTs, SMA/MA, dan SMK. 
Jakarta: Depdiknas, Balitbang, Puslit Pendidikan.

Depdikbud, $1995 . \quad$ Petunjuk Pelaksanaan Proses Belajar Mengajar. Jakarta.

Dryden, G. dkk. 2002. Revolusi Cara Belajar (The Learning Revolution): Belajar Akan Efektif Kalau Anda Dalam Keadaan "Fun" Bagian I dan II: Keajaiban Pikiran. Penerjemah Ahmad Baiquni. The Learning Revolution: to Change the Way the World Learns. 1999. Bandung: Kaifa.

Hasan, H. 1996. Inovasi Dalam Kurikulum Pendidikan Dasar dan Menengah. Bandung: PPS IKIP Bandung.

Hassoubah, Z. I. 2007. Mengasah Pikiran Kreatif dan Kritis: Disertai llustrasi dan Latihan. Terjemahan Bambang Suryadi. Developing Creative \& Critical Thinking Skills: A Handbook for Students. 2002. Bandung: Nuansa.

Ibrahim, M. dan Nur, M. 2000. Pengajaran Berdasarkan Masalah. Surabaya: University Press.

Janulis P. P. 2004. Pengembangan Dan Implementasi Pembelajaran Sains Menggunakan Model pembelajaran berdasarkan masalah. (Makalah disajikan dalam Konvensi Nasional Pendidikan Indonesia V), Surabaya, 5 - 9 Oktober 2004.

Jatmiko, B. 2004. Model-Model Pembelajaran (DI Kooperatif, Dan PBI). (Makalah disajikan pada Seminar Lokakarya FPMIPA di IKIP Negeri Singaraja), Singaraja, 27 November 2004.

Joyce, B and Weil, M. 1986. Model of Teaching. (Third Edition) Englewood Cliffs. New York: Prentice-Hall. Inc.
Kosasih, A. D. 1992. Menelusuri Dunia Afektif. Bandung: Lab. PMP \& KN FPIPS IKIP Bandung.

Mardjiono, D. 1994. Belajar dan Pembelajaran. Jakarta. Depdikbud.

Nurhadi. 2004. Pembelajaran Konstektual dan Penerapannya Dalam KBK. Malang: UM Press.

Oemar, H. (2004). Proses Belajar Mengajar. Bandung: Bumi Aksara.

Priatmoko, D.H. 2003, Reformasi Pendidikan Indonesia, Suatu Solusi dari Krisis, Makalah dalam Website, Balitbang Diknas.

Rostiyah. 1992. Didaktik Metodik. Jakarta. Bumi Aksara.

Rusyam, dkk. 1992. Penuntun Belajar Yang Sukses. Jakarta. Nine Karya Jaya.

Santyasa. 2004. Pengaruh Model dan Seting Pembelajaran Terhadap Remediasi Miskonsepsi, Pemahaman Konsep, dan Hasil Belajar Fisika pada Siswa SMU. Disertasi (tidak dipublikasikan). Malang: Program Studi Teknologi Pembelajaran Program Pascasarjana Universitas Negeri Malang.

Semiawan, Conny dkk, 1992 Pendekatan Keterampilan Proses, Jakarta: Gramedia Widiasarana Indonesia.

Soedijarto. (1993). Memantapkan Sistem Pendidikan Nasional. Jakarta: Gramedia

Soetomo, 1993. Meningkatkan Interaksi Belajar Mengajar. Surabaya: Sinar Baru.

Sudjana, N. 1995. Cara Belajar Peserta didik Aktif dalam Proses Belajar Mengajar. Bandung: Sinar Baru Algensindo. 
Sudjana, N. 2006. Penilaian Hasil Proses Belajar Mengajar. Cetakan kesebelas. Bandung: PT Remaja Rosdakarya

Sukardi, 2003. Metodologi Penelitian Pendidikan Kompetensi dan Praktiknya. Cet. 1. Jakarta: PT Bumi Aksara

Suma, K. 2004. Pembelajaran Berbasis Masalah (Problem Based Learning). (Makalah disajikan pada Seminar Lokakarya FPMIPA di IKIP Negeri Singaraja), Singaraja, 27 November 2004.

Suparno, P. 1997. Filsafat Konstruktivisme dalam Pendidikan. Cet. Ke-7. Yogyakarta: Kanisius.

Suwarma, Al, M. 1992. Pengembangan kemampuan Berpikir dan Nilai Dalam Pembelajaran PPKn. Disertasi (tidak diterbitkan). Bandung.

Suwarsih, M. 1994. Panduan Penelitian Tindakan. Lembaga Penelitian IKIP Yogyakarta. Yogyakarta.

Syaiful, B, D. (1994). Prestasi Belajar dan Kompetensi Guru. Surabaya: Usaha Nasional.

Trianto. 2010. Mendesain Model Pembelajaran Inovatif-Progresif:
Konsep Landasan dan Implementasinya Pada Kurikulum Tingkat Satuan Pendidikan (KTSP). Cetakan Ke-3. Jakarta: Kencana.

Wahidin, D. 2002. Pengembangan Daya Nalar Peserta didik Pendidikan Dasar. Khazanah Pengajaran IPA 1 (3). : 35 - 43.

Wardani. 1983. Keterampilan Memimpin Diskusi Kelompok Kecil. Jakarta. Depdikbud Dirjen Dikti.

Warpala, S. 2006. Pengaruh Pendekatan Pembelajaran Dan Strategi Belajar Kooperatif Yang Berbeda Terhadap Pemahaman dan Keterampilan Berpikir Kritis Dalam Pembelajaran IPA SD. (Disertasi). Program Studi Teknologi Pembelajaran PPS Universitas Negeri Malang

Wartono, dkk. 2004. Materi Terintegrasi Pelatihan Sains. Jakarta: Depdiknas Dirjen Dikdasmen.

Winarno, S. 1980. Pengantar Interaksi Mengajar Dasar dan Teknik Metodologi Pengajaran. Karya Jaya 